2nd International Conference Global Ethics -Key of Sustainability (GEKoS) | May 14, 2021 | Bucharest, Romania

\title{
Particularities in the Process of Implementing a Qualitative Management System in Romanian Secondary Schools, High Schools and Technical Vocational Schools
}

\author{
Carmen IONIȚĂ (VIŞOIU)
}

https://doi.org/10.18662/lumproc/gekos2021/20

How to cite: Ioniţă (Vişoiu), C. (2021). Particularities in the Process of Implementing a Qualitative Management System in Romanian Secondary Schools, High Schools and Technical Vocational Schools. In A. Grigorescu \& V. Radu (vol. ed.), Lumen Proceedings: Vol. 15. 2nd International Conference Global Ethics - Key of Sustainability (GEKoS) (pp. 225-238). Iasi, Romania: LUMEN Publishing

House. https://doi.org/10.18662/lumproc/gekos2021/20 


\title{
Particularities in the Process of Implementing a Qualitative Management System in Romanian Secondary Schools, High Schools and Technical Vocational Schools
}

\author{
Carmen IONIT,Ă (VIŞOIU) ${ }^{1}$
}

\begin{abstract}
In order to achieve prosperity and competitiveness, a relevant educational system strongly linked to the economy and the society of the future is required. The authorities cannot certainly say that our country has a well-defined strategy regarding the human capital management, one that is conform to the European Union. Strategies based on lifelong learning are being discussed and analysed. As statistics show, the existing strategy implementation is weaker in the Romanian educational system compared to other European educational systems. The paper focuses on highlighting the main priorities in the process of implementing a qualitative management system in Romanian secondary schools, high schools and technical vocational schools, a modern education that fulfils the market needs.
\end{abstract}

Keywords: quality, educational management, quality management, performance.

$1 \mathrm{PhD}$ student, "Valahia" University of Targoviste, Doctoral School of Economics and Humanities, Lt. Stancu Ion Street, Nr. 35, Targoviste, Romania, ionyta carmen@yahoo.com 


\section{Introduction}

Lately, in today's society, the qualitative management in preuniversity education has become increasingly important, so the role of this type of management in the educational system has become an important topic of debate at all levels.

The educational system represents an important area of our society, so people must be prepared and acquire knowledge to be successful. For this reason, the management, quality, and efficiency of the educational system need a scientific foundation based both on the science of the educational management and on the achievement of quality indicators (Călugărescu \& Preda, 2018).

As today's society relates to quality and efficiency, the issue of qualitative management in pre-university education has become significant in the current social environment and especially in educational activities.

We can say that the majority problems in the educational management appear due to the multiple changes in the system, also by the inability of educational actors to adapt and accept these changes.

Quality-focused educational management systematically values the community perspective, the school perspective, which proposes an education, defined as an authentic social exercise. In this context, based on continuity and change, the preoccupation to analyse the characteristics of the qualitative management becomes legitimate (Mkoma \& Rwekaza, 2021). The qualitative management is an option related to educational policy. The differences between the educational systems of different countries need a common system of general principles and values, which will help the elaboration of national quality management models.

The evolution perspectives of the qualitative management in different fields were highlighted by the philosophy that was the basis of the theories, of the quality models (Bădescu et al., 2017).

Qualitative management principles having a legislative framework with effective quality policies, are mainly focused on action, on the expectations and needs of direct and indirect beneficiaries, on carrying out activities, involving their own staff, oriented towards goals and objectives appropriate to reality and to the axiological register of organizations, on the organization, beyond the bureaucratic model, of simple forms leading to the assurance and monitoring of quality in an open stimulating environment (Hava, 2013).

Efforts to approach quality, as a dynamic and complex concept, in an integrative vision, bring a new challenge: total quality management. Thus, a new way of reporting to the field of quality appeared where the focus on 
the process and on the beneficiaries can be identified. This problem will increasingly be valued and promoted by modern organizations that are deeply anchored in the reality of our society.

In fact, the quality assurance approach is conditioned by the supportive attitude towards it, by the strategies that ensure and promote quality as a process, product, and result.

There is still a reservation concerning the evaluative dimension of quality, the evaluation itself, being considered as a context for the application of sanctions and corrective measures (Cucui et al., 2010). The essence of the evaluation is to notice aspects that require intervention in the sense of improvement, to identify development measures, not to have as exclusive purpose (as it appears in the perception of the members of the organization) coercive interventions (Călugărescu \& Preda, 2018).

Quality policies at the level of the organizations configure with the active involvement of staff in various stages: consultation, counselling, decision, making, execution, monitoring and evaluation. Even if we try to harmonize policies at national and European level, the freedom of choice of states for the development of their own quality systems remains (Iosifescu, 2007). In the Romanian space, the educational system and the quality system are centralized, the principle of decentralization being, in the perception of the actors in the school communities, an element, which must be included in the agenda of the decision-makers (Popovici et al., 2020).

\section{Qualitative management system in education}

Higher education characterized by a diversity of institutions, with multiple, multidisciplinary training programs, with a significant number of students can lead to the impossibility of universities to become elite in favour of mass education.

Elite education requires the existence within universities of highperformance research programs, well-trained teachers, attractive training programs, educational management connected to educational performance, the ability to adapt to the European space of university education (Soedarso, 2020).

As such characteristics and needs have a relevant influence on ensuring the quality of higher education, the correspondences between the dynamics of the higher education system or institutions and the approach to quality are fundamental. In accordance with the legislation, the achievement and evaluation of quality have an external and an internal dimension (Maer Matei et al., 2018). 
Quality, as a dimension of one's own organization, requires finding and implementing an optimal organizational structure for the quality system. Such a structure is based on the principles of delegation the responsibility and authority at all relevant levels, the elicitation of a balance between the managerial decision and the beneficiaries (external clients, staff, and students at the university), and also the prevention of an inefficient quality management at the university level (State, 2020).

Referring to pre-university education we can say that obtaining quality and, implicitly, the trust of beneficiaries requires that the principles of quality to be explicitly formulated, as they guide the concrete management of quality (both in terms of respecting the issues and even exceeding the beneficiaries' expectations) (Barbu, 2010). The principles, related from the fundamental values assumed at the level of the school system, must be part of the organizational culture of each school unit (Datutusta et al., 2020).

Educational management appears in different structures: macro management achieved in national or European education system; intermediary-management performed in educational institutions; micromanagement achieved in classes.

The levels where the management is used in an educational unit are the same as in any functional organization, such as: top management (top management at the top of the organization/management level), middle management (areas management- at the level of commissions / departments), first level management (class management-students' groups management) (Ene, 2018).

Educational managers are people who, using a series of laws, principles, methods, etc., depending on personal skills, lead a certain hierarchical level in the school organization to achieve the goals. From this perspective, the literature presents the following types of educational managers (State, 2020):

- nursery schoolteacher, primary school teacher, secondary schoolteacher.

- form master.

- speech therapist.

- counsellor/ aide teacher.

- methodologist teacher.

- headmaster.

- school inspector.

- high school teacher.

- university manager. 
When we talk about educational management, we must refer to the ability to produce educated students, with skills and abilities necessary for society and expected by them. The actions teachers must use should base on the existence of training programs adapted to the needs of the market and capable at any time to be changed, innovated (Ştefan et al., 2009). The development of an efficient management requires the establishment of clear and structured objectives together with the existence of educated managers who can lead the human resource and use the material one to achieve the expected goals (Ene, 2018).

At macro level, educational management must be able to formulate what goals should achieve, what structure the needed institutions should have, what knowledge students should acquire, to elaborate the necessary legislative framework, to ensure the training of the management staff and the necessary framework for checking and subsequently adjusting the leading process (Dincă, 2017). They are also useful in analysis, after measuring and improving specific teaching activities.

\section{Specific priorities in the process of implementing a qualitative management system}

Every educational system in the world is going through a reforming process nowadays. And it's not enough. The reform does not help because it only improves a broken model. What we need is not an evolution, but a Revolution in education. It needs to be turned into something else. One of the real challenges is to fundamentally innovate in education (Marin Barbu et al., 2020).

We try to carry out some measures to improve technical educational management in Romania, considering that the essential change that is required is that of paradigm.

It is known that public education systems were created for the needs of the industrialism in the middle of the 18th century. The sound of the bell, the specialization on subjects taught in schools, the grouping of students according to their age, all these aspects reproduce the idea of production line. The existence of public education systems was determined by the economic conditions of the time and was based on an intellectual model of the mind, which practically represented the view of the Enlightenment over intelligence: academic ability (Stegăroiu et al., 2020).

To promote the country's prosperity and competitiveness, a relevant education system is needed in relation to the economy and society of the future (Radu et al., 2011; Yeo et al., 2020). 
Statistical data and analyses carried out at the level of the Romanian educational system, i.e., comparisons with other European countries demonstrate the poor performance in the implementation of existing strategies.

To fulfil the need of our country to have a high school educational system proper to modern requirements, a new educational system has to be achieved. It must contain the following solutions to improve the technical educational management (State, 2020):

- Consistency in the implementation of educational strategies, their long-term realistic, motivating conception, their assumption by the whole civil society.

- Democratization and depoliticization of the educational system.

- Decentralisation and autonomy.

- Ensuring adequate funding for education.

- Development of partnerships and communication between all the institutions interested in education and training. These are possible through the involvement of all partners: parents, business environment, civil society.

- Implementing a personalized and flexible curriculum.

- Real monitoring of the student's evolution, skills and guidance to educational information that support the maximum development of his potential.

- Linking education to the labour market by constantly and consistently carrying out regular prospective studies concerning the evolution of the labour market. In relation to these, the systematic analysis of needs and the demand for education and training is carried out.

- Developing functional school transition schemes from school to the labour market. (Information, materials, transition ways to the labour market)

- Equal access to information on the existing educational and professional platforms for disadvantaged families (concerning their social origin or level of education).

- Adapting the educational curriculum to the labour market and to the needs of today's society.

- The real practice of an interactive, student-centred pedagogy.

- Developing students' real entrepreneurial skills.

- Increasing schooling among young people in rural areas using nonrefundable funding facilities for teachers and pupils. 
- Promoting equal access to various high school educational offers.

- Workplace learning activities (practical training courses offered by a potential employer)

- Practical implementation of legal public services.

Starting from the idea that qualitative management in pre-university educational system is a coherent and reflexive action at the same time, we can say at this moment that this management system can be perfected (Wilk, 2018).

Thus, new approaches have emerged regarding the premises that lead to the achievement of a qualitative education by labelling a school like a 'good school'.

According to the new approaches, a good school functions as an effective and fair structure for all children, guarantees the minimum "civilization" of its graduates, in the sense of adopting a good citizen behaviour, all its students' progress, ensures that each student achieves the highest performance that he is capable of, ensures each child the opportunity to form attitudes, skills and less knowledge accumulation, concerns about the development of a child's personality elements, continuously improves and becomes a learning organization, an institution able to infuse any beneficial change generated by the level of the society and education (Călugărescu \& Preda, 2018).

In this sense, the chances of ensuring a good quality education for children are more significant in a school where the physical environment is clean, neat, and welcoming, the general atmosphere is relaxed and friendly, the hidden curriculum is in full agreement with the formal one (Vasile et al., 2007).

These opportunities will become even greater as students are involved in activities that can improve the physical and socio-affective aspects of the school environment. To respond to this desire, the teachers must also make the students feel "the owners" of that school and give them the opportunity to implement their own ideas (Bădescu et al., 2017). By having a relevant contribution to the improvement of the environment in their school, children will appreciate the changes made and will respect their efforts. Studies have shown that elements related to the physical environment and the school climate as well as initiatives related to children's involvement in improving these elements have a special contribution in ensuring a good quality education.

Quality and efficiency are two important pillars of education reforms around the world. They must be considered when we build the national system of management and quality assurance in Romanian education. 
Achieving quality in education is necessary because Romania is one of the few European countries that did not have a law in this area. That is why it was also necessary to establish the legislative framework that would allow the development of an institutional culture of quality in education and the protection of the educational beneficiary.

Considering the Education Law No. 84/1995, republished with subsequent amendments and additions and the Constitution of our county, the Romanian government adopted the emergency ordinance concerning the insurance of quality in education. It provides for general rules, methodology, internal assurance of a qualitative education, external evaluation of a qualitative education, accreditation of educational providers and study programmes (State, 2020).

The general framework concerning the fields, criteria, standards, and procedures for assessing and ensuring quality at the level of the national education system is be found in the General Methodology of Evaluation and Quality Assurance of Education. According to this methodology, quality assurance of education is mainly centred on learning outcomes expressed in terms of knowledge, skills, values and attitudes and covers three fundamental areas, for which specific criteria are established. These areas are institutional capacity, educational effectiveness, and quality management (Tudorică, 2007).

Institutional capacity results from the internal organisation and infrastructure available to fulfil the objectives of the educational programmes. The institution must have a management and administration system, a material basis and financial resources necessary for a stable shortand medium-term functioning, as well as human resources it can rely on, to achieve the proposed assumed objectives. The school principal is responsible for all these issues (Mkoma \& Rwekaza, 2021). Educational effectiveness consists in mobilizing human and financial resources to get students to achieve the best possible results in learning (Tudoran Niculiţă et al., 2020).

The evaluation criteria corresponding to the educational effectiveness refer to designing the objectives and results, organizing the framework for learning, educational process, human resources, curricular resources, ethos, school climate and culture, community relations and partnerships (Datutusta et al., 2020).

Qualitative management results from the structures, practices and processes that ensure the continuous improvement of educational services in the institution. It must be centred on those strategies, structures, techniques, and operations the institution used to demonstrate that it assesses its performance in ensuring and improving the quality of education and has 
information systems demonstrating the results obtained in learning. The institution must manage the quality assurance of all its activities and make public information and data that proves a certain level of quality (Maer Matei et al., 2018).

Management improvement in technical education in order to increase young people's integration into the labour market refers mainly to the implementation of some systems and evaluation tools and to the anticipation of need skills, which will lead to the most attractive qualitative and relevant training offer from schools (Tăbîrcă et al., 2019).

The existence, at the central level, of a well-structured qualifications framework and a coherence and consistency of policies related to education, employment and economy ensure the support for the improvement of a strategic management in vocational and technical education (Cucui et al., 2010). The realization of a well-structured qualifications framework must be transparent, involving all the institutions interested in the development of quality-assured qualifications (Popovici et al., 2020).

\section{Conclusions}

Technical education units must integrate in their strategic planning a well-developed strategy to promote the educational offer. Its effects and the good information of all interested factors related to the support and professional orientation for students and parents lead to the increase of notoriety of technical education and the valorisation of the obtained professional competences, very important effects in the current situation. We can notice that the number of students has receded over the years, due to the decline of the school population as a whole and due to the inconsistent changes during this period in the structure of this form of education. Megatrends related to digitalization, globalization, technological evolution, environmental change, the aging of companies guide the future trends concerning the jobs, the time and the people involved. References refer to the skills needed to enter to the labour market as well as to the opportunities of a career development.

Developing of innovation and national and international cooperation related to professional training is essential to ensure the success of vocational and technical education. Delayed responses lead to a lack of employment, or a lack of graduates' skills needed to find a job.

Direction, concentration, and consistency are the essence of any institution's strategy. Technical education units must implement a 
management model that ensures a mass, beneficial and motivating innovation trend for all actors involved.

Economic agents' involvement, as well as of other important factors in the decision-making and consultation mechanisms concerning the school organization directs the action towards the maximum responsibility of those involved and leads to the innovation and diversification of the educational offer.

Dual education implementation is a form of improving educational management in technical education. The adopted strategy combines on-thejob learning provided by partner economic agent, with education and training in an educational unit and represents a chance offered by the vocational and technical education system, for an active and long-term collaboration between school, companies, and students.

The strategic approach aims to develop mechanisms to anticipate the skills required in the labour market, accurately define professional profiles, to develop / review skills according to abilities and knowledge relevant to labour market needs and adapt learning programs to the needs and trends of the society. The economic operator requests a tuition fee and concludes a partnership contract with the vocational and technical education unit on the one hand and with the local administrative unit on the other hand. The state, represented by the local administrative unit, offers a series of incentives for economic agents who want to get involved in such a project. We can find the benefits in the methodology related to the implementing of dual vocational education concept for the current year and they refer to the facilities regarding the payment of taxes, fees and contributions. In addition to this, they benefit from the deduction of all expenses occurred during the dual education.

Changes in the content of software skills are just as important as changes in the content of technical or hardware skills. Computer information skills are required regardless the qualification level, "green" skills should also be mastered and assimilated in all areas along with communication skills, teamwork, collaboration, creativity, innovative thinking, problem solving, flexibility, the ability of learning how to learn as well as the awareness of the importance of lifelong learning for both graduates and those who provide training.

The analysis of fluctuations in employment and future development trends can provide a scientific basis for vocational and technical education to develop training strategies. Studying the local, regional, and national level features and taking into account the characteristics of the labour market, the existing balances and imbalances that appear on this market can be solved. 
The specialized literature, due to the increased number of studies related to the agents with a critical role on improving the strategic management in institutions, considers the quality of the staff, the teachers, and the innovation very important. Therefore, the performance in the teaching career influences the students' results and their answers during the interviews carried out with the economic agents and practical partners of the vocational and technical education units.

The quality of the educational act should undoubtedly represent a priority for each teacher involved in the complex approach of the instructive-educational process. The change of jobs or the teachers' professional reconversion, talking about the ones belonging to vocational and technical education system, where, nowadays, massive decreases in the employment rate have occurred, is a good and viable solution to adopt. Ensuring optimal conditions for teachers' training and their continuous professional development is a reference pillar in strategic planning, for each school organization.

\section{References}

Bădescu, G., Negru-Subțirică, O., Angi D., Ivan C. (2017). Profesor în România. Cine, de ce, in ce fel contribuie la educația elevilor in școlile românestit? [Teacher in Romania. Who, why, in what way contributes to the education of students in Romanian schools?]. http://library.fes.de/pdffiles/bueros/bukarest/14003.pdf

Barbu, L. (2010). Managementul calității [Quality Management]. Sf. Ierarh Nicolae Publishing House.

Călugărescu, A., \& Preda, M. (2018). Management of Educational Efficiency and Efficiency. HOLISTICA - Journal of Business and Public Administration, 9(3), 89-96. https://doi.org/10.2478/hjbpa-2018-0025

Cucui, I., Toplicianu, V., Popescu, C., Duică, A., Cucui, G., Duică, M., \& Radu, F. (2010). Inserţia absolvenţilor de invăţământ superior [Insertion of higher education graduates]. Bibliotheca Publishing House

Datutusta, I., Rochmah, S., \& Amin, F. (2020). Quality of Functional Services for Private University Lecturers (Studies at the Office of LLDIKTI Region VIII). HOLISTICA - Journal of Business and Public Administration, 11(2), 5262. https://doi.org/10.2478/hjbpa-2020-0018 
Dincă, D. (2017). Perspectives Regarding the Prefect Institution in Romania. HOLISTICA - Journal of Business and Public Administration, 8(1), 7 14. https://doi.org/10.1515/hjbpa-2017-0001

Ene, A. B. (2018). Distance Education in Romanian Higher Education. HOLISTICA - Journal of Business and Public Administration, 9(1), 6570. https://doi.org/10.1515/hjbpa-2018-0005

Hava, F. (2013). Organizatii, grupuri de interese şi management educațional [Organizations, interest groups and educational management]. Cluj University Press

Iosifescu, C. Ş. (2007). Calitatea educaţiei. Concept, principii, metodologii [Quality of education. Concept, principles, methodologies]. Educația 2000+ Publishing House.

Maer Matei, M. M., Mocanu, C., \& Zamfir, A. (2018). Educational paths in Romania: choosing general or vocational education. HOLISTIC A - Journal of Business and Public Administration, 9(2) $127-$

136. https://doi.org/10.2478/hjbpa-2018-0016

Marin (Barbu), C. A., Condrea, E., \& Popovici, N. (2020). Quality Management in the Hotel Industry in the Macro-Regions of Romania. In A. Grigorescu \& V. Radu (vol. ed.), Lumen Proceedings: Vol. 11. 1st International Conference Global Ethics -Key of Sustainability (GEKoS) (pp. 182-191). Iasi, Romania: LUMEN Publishing House. https://doi.org/10.18662/lumproc/gekos2020/19

Mkoma, R., \& Rwekaza, C. (2021). Decentralization in Tanzania: Perceptible Efficiency and Effectiveness in Management of Community Health Care, Free Basic Education and Public Private Partnership. HOLISTICAJournal of Business and Public Administration, 12(1), 57-

68. https://doi.org/10.2478/hjbpa-2021-0006

Popovici, N., Munteanu-Florea, I., \& Condrea, E. (2020). A Perspective on Quality of Life. In A. Grigorescu \& V. Radu (vol. ed.), Lumen Proceedings: Vol. 11. 1st International Conference Global Ethics -Key of Sustainability (GEKoS) (pp. 4555). Iasi, Romania: LUMEN Publishing House. https://doi.org/10.18662/lumproc/gekos2020/06

Radu, F., Radu, V., \& Croitoru, G. (2011). The advantage of the new technologies in learning. 10th international conference on Artificial intelligence, knowledge engineering and data bases. 150-155.

http:/ / citeseerx.ist.psu.edu/viewdoc/download;jsessionid=2DE215C4530 $\underline{\text { BF9FEFE163C8227131DE0?doi=10.1.1.452.8550\&rep }=\text { rep1\&type }=\text { pdf }}$ 
Soedarso, S. (2020). Achievement of Management Performance Business Banking Using Measurement Model System Quality Management Canadian Award for Excellence (SQMCAFE) Case Study : PT. Bank Bjb (Jabar-Banten) Tbk. Indonesia. HOLISTICA - Journal of Business and Public Administration, 11(1), 95-106. https:/ /doi.org/10.2478/ hjbpa-2020-0009

State, M. (2020). The Efficiency of Entrepreneurial Education Programs in Romania. In A. Grigorescu \& V. Radu (vol. ed.), Lumen Proceedings: Vol. 11. 1st International Conference Global Ethics -Key of Sustainability (GEKoS) (pp. 6573). Iasi, Romania: LUMEN Publishing House. https://doi.org/10.18662/lumproc/gekos2020/08

Ştefan, V., \& Granic, A. (2010). Delivery of education and training frameworks through mobile technologies. Conference proceedings of »eLearning and Software for Education« (eLSE), 6(01), 39-46. https://www.ceeol.com/search/articledetail?id $=129026$

Stegăroiu, I., Radu, V., Simsek, H., \& Tăbîrcă, A. I. (2020). Impact of Leadership Team Values and Performance on Organizational Behavior. In I. Panagoreț \& G. Gorghiu (vol. ed.), Lumen Proceedings: Vol. 10. International Conference Globalization, Innovation and Development. Trends and Prospects (G.I.D.T.P.) (pp.241-251). Iasi, Romania: LUMEN Publishing House. https://doi.org/10.18662/lumproc/gidtp2018/27

Tăbîrcă, A. I., Ivan, O. R., Radu, F., \& Djaouahdou, R. (2019). Qualitative Research in WoS of the Link between Corporate Social Responsibility and Corporate Financial Performance. Valabian Journal of Economic Studies, 10(1), 107-118. https://www.proquest.com/docview/2330032347/fulltextPDF/BAB56E $\underline{10962546 \mathrm{~F} 1 \mathrm{PQ} / 1 \text { ? accountid }=87693}$

Tudoran (Niculiță), V.I., Oprişan, O., \& Dumitrache (Şerbănescu), A.M. (2020). Implementation of the Integrated Management System for Quality -Food Safety -Development Strategy for the Dobrogea Tourism Service. In A. Grigorescu \& V. Radu (vol. ed.), Lumen Proceedings: Vol. 11. 1st International Conference Global Ethics -Key of Sustainability (GEKoS) (pp. 236-245). Iasi, Romania: LUMEN Publishing House. https://doi.org/10.18662/lumproc/gekos2020/24

Tudorică, R. (2007). Managementul educației în context European [Management of education in a European context]. Meronia Publishing House

Vasile, V., Zaman, G., Pert, S., \& Zarojanu, F. (2007). Restructuring Romania's education system considering the evolutions from the domestic market perspective and impact on RDI progress. European Institute of Romania - Strategy and Policy 
Studies (SPOS), 2. http://ier.gov.ro/wp-

content/uploads/publicatii/Spos2007_studiu_2_en.pdf

Wilk, K. (2018). The best educational systems in the world on example of European and Asian countries. HOLISTICA - Journal of Business and Public Administration, 83), 103-115. https://doi.org/10.1515/hjbpa-2017-0028

Yeo, A. C. M., \& Lai, M. E. K. (2020). The Influence of B2B Relationship Quality on Opportunism and Firm Performance. HOLISTICA - Journal of Business and Public Administration, 11(3), 59-87. https://doi.org/10.2478/hjbpa$\underline{2020-0032}$ 